\title{
Sustainability of University Campuses; Bilecik Seyh Edebali University Example, Bilecik/Turkey
}

\author{
Hilal Kahveci ${ }^{1}$ \\ 1* Bilecik Seyh Edebali University, Faculty of Fine Arts and Design, Departmant of Interior Architecture and Environmental Design, Bilecik, Turkey, (ORCID: 0000- \\ 0002-4516-7491), hilal.kahveci@bilecik.edu.tr
}

(First received 16 August 2021 and in final form 6 October 2021)

(DOI: $10.31590 /$ ejosat.983505)

ATIF/REFERENCE: Kahveci, H. (2021). Sustainability of University Campuses; Bilecik Seyh Edebali University Example, Bilecik/Turkey. European Journal of Science and Technology, (27), 810-817.

\begin{abstract}
Cities provide people with unnatural environments where green areas decrease and environmental problems arise along with modern life. Population growth, water and air pollution, especially climate change, deforestation, and species decline are some of the increasing environmental problems in urban areas. The concept of 'sustainability' has come to the fore in order to prevent environmental problems that arise worldwide and to protect ecosystems. The sustainable urbanization approach includes all environmental (built environment/natural environment), social and economic factors that are affected by urban development and that affect urban development in an interrelated manner, and predicts combining economic and social development with the aim of environmental protection and improvement. In this context, university campuses, which are an extension of urban areas, can act as a laboratory as an example of a small city model on a pilot basis.

The fact that the socio-cultural level and environmental awareness rate of university students and staff are higher than those living in urban areas will ensure more efficient sustainable practices in campus areas. In this study, the situation of the university campuses and the landscape components of the Bilecik Şeyh Edebali University campus area regarding the concept of 'sustainability' has been examined. In Bilecik Şeyh Edebali University campus, minimizing the use of natural resources, integrated waste management, water management to reduce the effects of global warming, and long-term holistic planning approaches have been discussed. In addition, proposals have been presented by considering innovative approaches in the planning and design of campuses and urban areas within the scope of the basic principles of sustainability specific to Bilecik Şeyh Edebali University campus. As a result, the importance of university campus areas for sustainable cities has been emphasized and it has been revealed that significant contributions to sustainability would be possible by cooperating with local governments.
\end{abstract}

Keywords: Environmental problems; Sustainability; University campus areas.

\section{Üniversite Yerleșkelerinin Sürdürülebilirliğgi; BŞEÜ Örneği, Bilecik/Türkiye}

\section{$\ddot{O} \mathbf{z}$}

Kentler insanlara çağdaş yaşamla birlikte, yeşil alanların azaldığı çevresel sorunların ortaya çıktığı yapay çevreler sunmaktadır. İklim değişikliği başta olmak üzere nüfus artışı, su ve hava kirliliği, ormanların ve bitkilerin azalması kentsel alanlarda ortaya çıkan çevresel problemlerden bazılarıdır. Dünya çapında ortaya çıkan çevre sorunlarının önüne geçebilme ve ekosistemlerin korunabilmesi için 'sürdürülebilirlik' kavramı gündeme gelmiştir. Sürdürülebilir kentleşme yaklaşımı, kentsel gelişmenin etkilediği ve kentsel gelişmeyi etkileyen tüm çevresel (yapılı çevre/doğal çevre), sosyal, ekonomik unsurları birbiriyle ilişkili biçimde olup; ekonomik ve sosyal gelişimin çevre koruma ve iyileştirme amacı ile birleştirilmesini ön görmektedir. Bu bağlamda kentsel alanların bir uzantısı olan üniversite yerleşkeleri pilot bazda, küçük birer kent modeli örneği olarak, adeta laboratuar görevini üstlenebilir. Üniversite öğrenci ve personelinin sosyokültürel seviyesinin, çevre bilinci oranının kentsel alanlarda yaşayanlara oranla daha yüksek olması yerleşke alanlarında sürdürülebilir uygulamaların daha verimli olmasını sağlayacaktır. Bu çalışmada üniversite yerleşkelerinin ve Bilecik Şeyh Edebali Üniversitesi kampüs alanındaki peyzaj bileşenlerinin 'sürdürülebilirlik' kavramı ile ilgili durumu irdelenmiştir. Bilecik Şeyh Edebali Üniversitesi yerleşkesinde doğal kaynakların kullanımının en aza indirilmesi, entegre atık yönetimi, küresel ısınmanın etkilerini azaltma için su yönetimi ve enerji verimliliğinin arttırılmasında uzun vadeli bütüncül planlama yaklaşımları ele alınmıştır. Ayrıca Bilecik Şeyh Edebali Üniversitesi yerleşkesi özelinde sürdürülebilirlik temel ilkeleri kapsamında kampüsler ve kentsel alanların planlama ve tasarım alanlarında yenilikçi yaklaşımlar ele alınarak öneriler geliştirilmiştir. Sonuç olarak sürdürülebilir kentler için üniversite yerleşke alanlarının önemi vurgulanmış yerel yönetimlerle işbirliği yapılarak sürdürülebilirliğe önemli katkılar sağlanacağı ortaya çıkmıştır.

Anahtar Kelimeler: Çevresel problemler, sürdürülebilirlik, üniversite kampüs alanları. 


\section{Introduction}

The main cause of global environmental problems that threaten all humanity is urbanization due to rapid population growth. Urbanization is one of the developments that occur as a result of humanity's excessive intervention in nature and that threatens natural resources the most (Erdoğan 2006; Dinçtürk et al. 2020). Rapidly growing urban areas are developing at the expense of fragmentation of natural areas and reduced ecosystem functionality. This situation reduces biodiversity and decreases the quality of human life gradually (Kop 2011). In order to cope with the negative consequences of urbanization and living conditions, planning and design approaches are reviewed for an environmentally friendly and sustainable life that respects the ecological cycle (Onur 2020). By ensuring the sustainability of cities, it is vital not only to solve the environmental problems but also to increase the quality of life of the current population and to create livable spaces where future generations can easily maintain their lives.

The rate of urbanization is increasing worldwide and it is predicted that this figure will reach higher rates by 2050 (Strokal et. al. 2021). Interventions to nature and natural areas where we live in mutual interaction are increasing and the rate of green space is decreasing day by day on a global scale. Today, the measures taken to solve these problems are evaluated under the general definition of "sustainable approach". Sustainability is considered to be an economic, social, and ecological concept. The term - "sustainable development" - was adopted by the Agenda 21 program of the United Nations in 1992 (Emanuel and Adams 2010). The UN Intergovernmental Panel on climate change bring out a report that says "urgent and unprecedented changes are needed to reach the target" of reducing the global warming. Also they say that countries must follow the Paris Agreement, conversely the world faces the complete degredation of corals and the melting of the Arctic ice caps (URL 5). With sustainable approaches, it is aimed to protect nature in its current form and to transfer it to future generations. In this context, rain gardens, vertical gardens, roof gardens, increasing permeable surfaces and the use of renewable energy in urban areas are some of these studies. These studies are at the focus of the landscape architecture profession as in many other professional disciplines (Bayramoğlu et. al., 2020).

Sustainability studies are on the agenda of the world, and various institutions and organizations have started to work on this issue. Sustainability in architecture certification system that Leadership in Energy and Environmental Design (LEED) was developed by US Green Building Council (USGBC) in 1998. The other is American Society Landscape Architects (ASLA) regarding sustainable certificiate system for lanscape architecture. Their criterias are sustainable topography, water efficiency, energy and atmosphere, materials and resources, air quality, reform and design phases, hydrology, soil, vegetation, human health and wellbeing (Arıdağ and Gürbüz, 2013). The European Environment Agency describes the objectives to be achieved in order to ensure urban sustainability (EEA 1995; Karakurt Tosun 2020):

- Minimizing the use of space and natural resources

- Managing urban flows effectively

- Protecting the health of the urban population

- Ensuring equal access to resources and services
Universities are the learning facilities for current and future leaders. They have the potential to provide innovative solutions to some of our greatest global challenges via their research activities. Universities have many spending opportunities, and solutions to improve human, ecosystem wellbeing, locally, and globally (Cole 2003; Özdoğan and Civelekoğlu, 2014). Universities give much attention to sustainability, but they too often disregard the problems of transportation and land use (Norton et al., 2007). The intensive discussion of the concept of sustainability by higher education institutions has started to question whether these institutions are also sustainable (Bilgili and Topal, 2021). According to the United Nations Environment Program-UNEP; Universities are micro-universes of environmental problems. The reason for this is that the society in the university is faced with all environmental problems, from greenhouse gas emissions to noise pollution (Özdoğan and Civelekoğlu, 2014). Most campuses have been designed as pedestrian campuses but in general culture encourages driving at every opportunity. This causes a pressure on campus management to develop parking lots, increase the size and number of roadways, and neglect the type of infrastructure that would encourage non-motorized transportation (Kaplan, 2015).

University campuses, an extension of urban areas, can act as a laboratory as an example of a small city model on a pilot basis with their population and many activities they take (Günerhan and Günerhan 2016). In addition, university campuses have an important place in the identity of the city with their social and cultural activities as well as education and training activities (Ertekin and Corbaci 2010). The fact that the socio-cultural level and environmental awareness rate of students and staff at universities are higher than those living in urban areas will ensure that sustainable practices are more efficient in campus areas (Iş1ldar 2015). The most basic principle to be considered for ecological landscape design in university campuses is the evaluation of the climate and topographic data that preserve the natural landscape character, the use of local/recyclable building materials and renewable energy sources in the design, the use of alternative green areas within the urban open-green area system and performing design studies that prefer natural vegetation in these areas. In this context, the sustainability indicators of universities are classified as effective use of climate data, regulations in energy and substance release, recovery of energy and waste, appropriate use of topographic data, effective use of natural resources and use of natural vegetation (Y1ldiz 2020). Addressing these indicators in urban planning and design approaches with various regulations is priority for a livable world. According to Günerhan and Günerhan (2016), in order to be a sustainable university; it is emphasized that research on sustainability should be encouraged, sustainability should be included in the curriculum in all disciplines, the importance of collaborations (public, governments, non-governmental organizations, private sector, other universities), and the need for interdisciplinary studies. Meetings and committees on sustainability are organized around the world and say that there is urgent need for every level of society to review their actions. In Canada Campus Sustainability Assessment Framework (CSAF)committee was established (Cole 2003). Also the United Nations Climate Change Conferences in Mexico (2010) and South Africa (2011) have further highlighted the need for a paradigm shift towards building a low-carbon sustainable society to deal with climate change (Too and Bajrachary, 2015). Velazquez et al. (2006) proposed a sustainable university model in their work (Figure 1). 


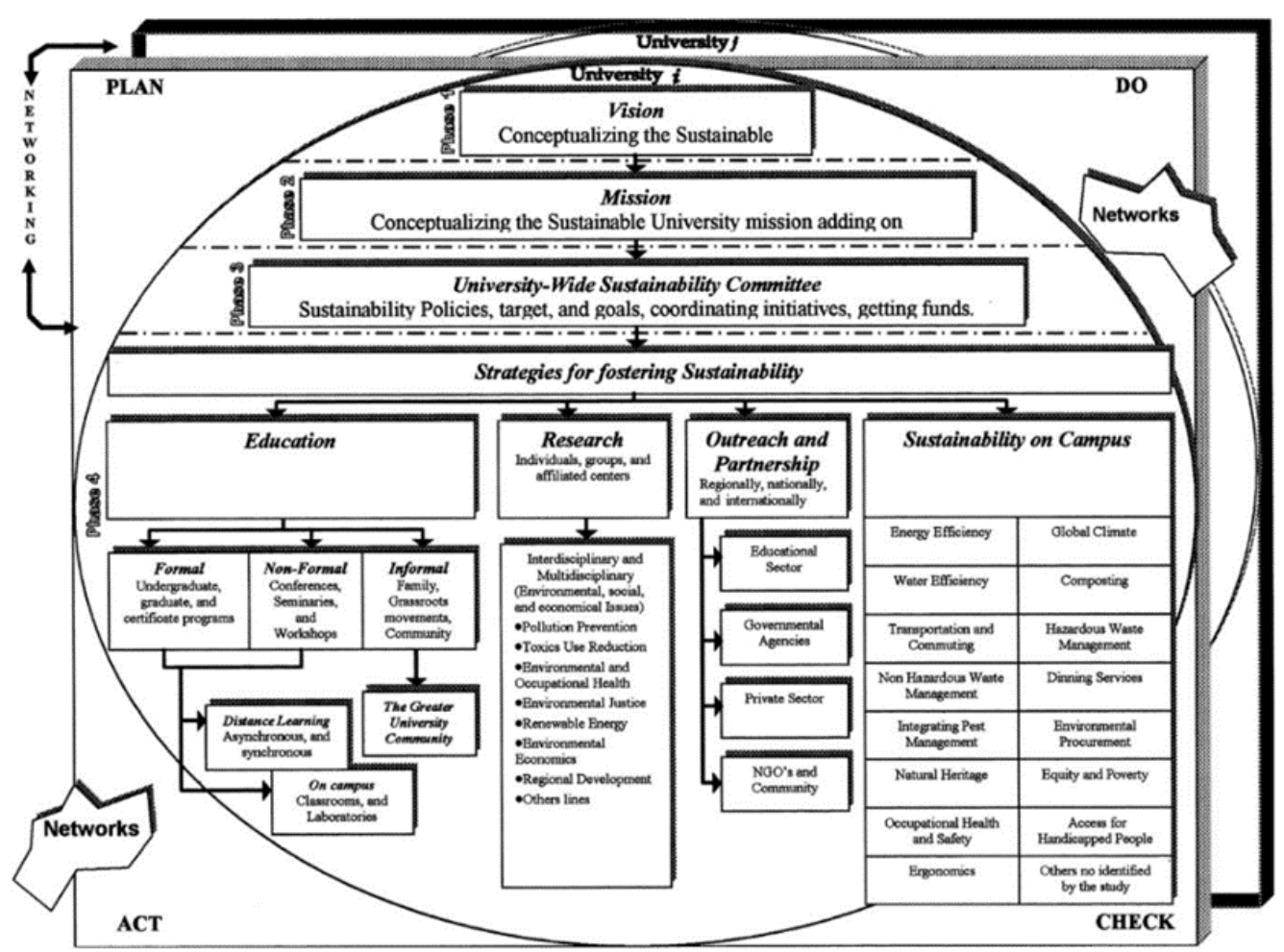

Figure 1. Sustainable university model (Velazquez et al. 2006).

In this context, the developing university campus in Bilecik has been determined as the study area, and its sustainable approaches have been discussed. In the light of all these data, our aims are;

- Addressing the issue of sustainability in university campuses, which are an important part of urban areas.

- Presenting the current sustainable studies on the BŞEÜ campus and offering alternatives to these studies.

- To raise awareness about sustainability and to make sustainable suggestions for the future.

\section{Material and Method}

\subsection{Material}

Bilecik Şeyh Edebali University, which was established in 2007, maintains its educational activities with 9 faculties, 1 institute, 1 college and 7 vocational colleges. As of 2020, the total number of students in the university is 16904, and there are 622 academic and 261 administrative staff, and this number is increasing every year. Being a developing university, it offers opportunities in terms of considering holistic approaches to sustainability in planning and design studies. In the study, the data of sustainable practice studies, maps and visuals in the BŞEÜ campus constitute the materials of the research.

\section{Study Area:}

The altitude of the study area is around $570 \mathrm{~m}$ and it is located at coordinates $40^{\circ} 11^{\prime} \mathrm{N}-29^{\circ} 58^{\prime} \mathrm{E}$ (Figure 2). BŞEÜ Gülümbe campus and has a $422500 \mathrm{~m}^{2}$ open area and $31316 \mathrm{~m}^{2}$ green area. In Bilecik, where BŞEU is located, autumn and winter months are rainy and summer is dry. In Bilecik, where a transitional climate is experienced, the average temperature varies around $19.0{ }^{\circ} \mathrm{C}$ throughout the year, and the annual precipitation average is around $458 \mathrm{~mm}$ (URL 1). In Bilecik, the characteristics of three plant geographies can be seen: Europe-Siberia, Mediterranean and Iran-Turan (Davis 1965; Erdem 2018). Thanks to its mild e-ISSN: 2148-2683 climate, Bilecik, where many plant species grow, also has important potential in terms of forest existence. Red pines growing in the Mediterranean climate, yellow pines and hazelnut trees growing in the Black Sea climate can be seen together in Bilecik geography (BEBKA, 2018).

\subsection{Method}

Within the scope of the subject, many studies were performed and analysis and synthesis stages were carried out (URL 2; URL 3; Siu Yu Lau et al. 2014). Various networks created today, such as the International Sustainable Campuses Network (ISCN), provide communication and coordination as the widest network of member universities in America, Europe and Asia with various study groups, seminars and conferences, and awards given. Another organization is the Green Metric University Sustainability Rating (URL 2,2021), which evaluates and compares sustainability efforts on university campuses worldwide. Within the scope of this study, ISCN, Green Metric criteria and sustainability criteria were obtained from many studies (Table 1). The method flow chart of the study is summarized in Figure 3. 


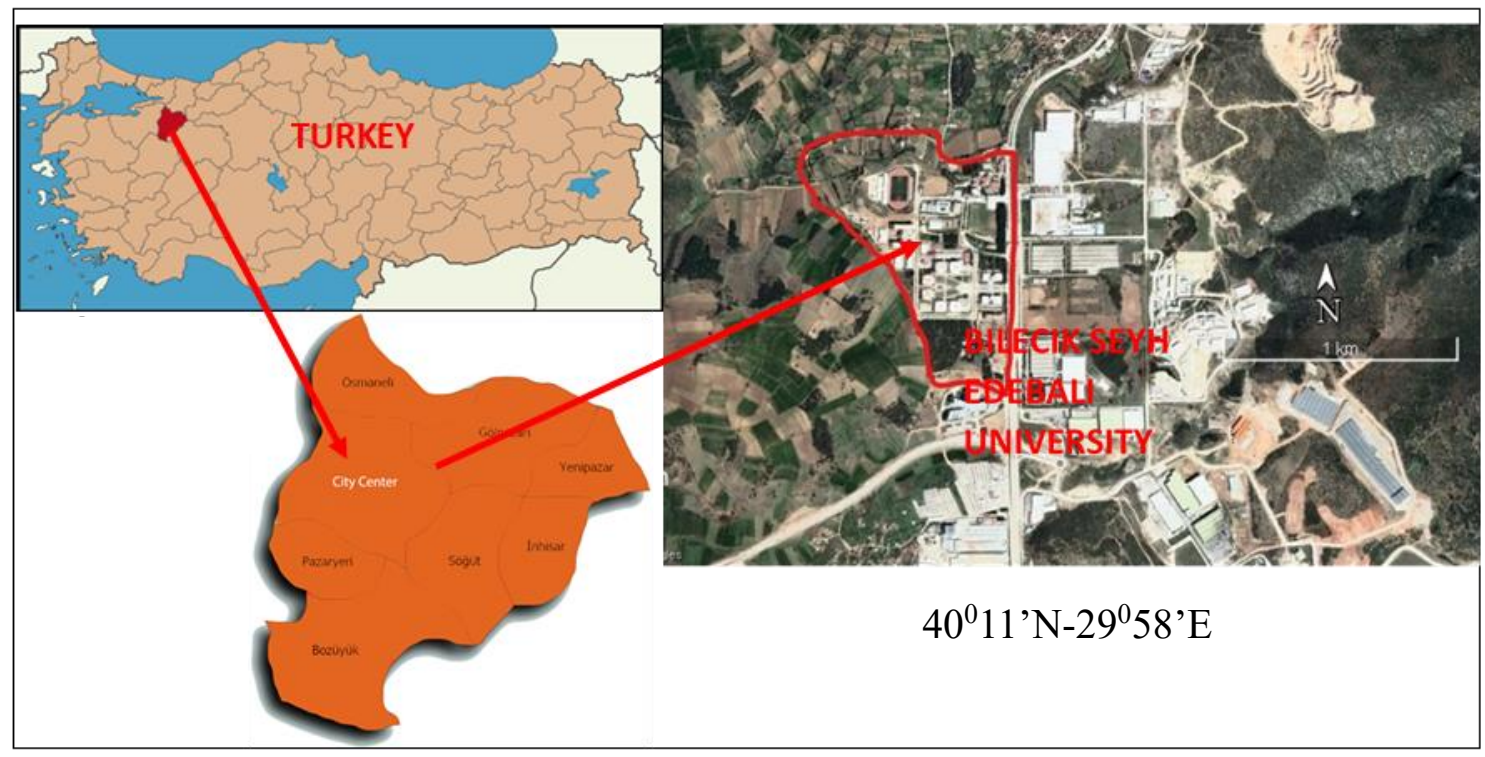

Figure 2. Study area

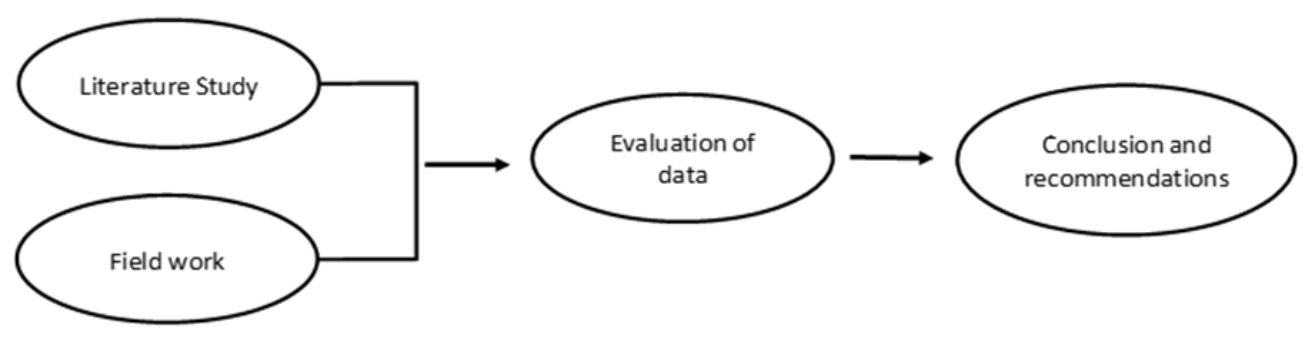

Figure 3. Study diagram

Table 1. Sustainability criteria

\begin{tabular}{|c|c|}
\hline Effective use of natural resources & $\begin{array}{l}\text { The use of natural vegetation, the use of plants with high water tolerance, use of natural } \\
\text { stones }\end{array}$ \\
\hline Water management & $\begin{array}{l}\text { Efficient use of water, treatment of wastewater at high levels with appropriate } \\
\text { technologies and reuse of treated water, water-efficient landscaping (gravel garden, } \\
\text { rock garden ect.) }\end{array}$ \\
\hline Energy and waste management & $\begin{array}{l}\text { Zero waste management and recycling studies, photocell lighting, energy-efficient } \\
\text { landscaping, reduction of electricity use }\end{array}$ \\
\hline Use of renewable energy & $\begin{array}{l}\text { Use of solar energy, wind energy, wave energy, geothermal energy, hydraulic energy, } \\
\text { biomass energy }\end{array}$ \\
\hline Clean transportation & $\begin{array}{l}\text { Minimizing harmful gases, to reduce greenhouse gas emission, pedestrianizing on- } \\
\text { campus transportation, directing the use of bicycles, increasing the use of electric } \\
\text { vehicles }\end{array}$ \\
\hline Accessibility & $\begin{array}{l}\text { It is the state in which all living individuals can access and use all public services without } \\
\text { the need of anyone }\end{array}$ \\
\hline $\begin{array}{l}\text { Protection and development of } \\
\text { ecosystems }\end{array}$ & Conservation and development of flora and fauna \\
\hline Creation of alternative green areas & $\begin{array}{l}\text { Increasing green surfaces, green roof and green wall design and increasing permeable } \\
\text { surfaces }\end{array}$ \\
\hline Awareness in the field of education & $\begin{array}{l}\text { Student involvement }- \text { looks at student participation in sustainability initiatives and } \\
\text { support for these activities by school administrators, the inclusion of courses on } \\
\text { sustainability in course curricula }\end{array}$ \\
\hline
\end{tabular}




\section{Results}

Within the scope of the study, the data were obtained from the departments related to the sustainability studies carried out on the campus of Bilecik Şeyh Edebali University. The sustainability studies carried out are listed below (Table 2).

Table 2. The sustainability studies in Bilecik Şeyh Edebali University

-Wastewater management
There is 1 wastewater treatment plant within the body of BŞEU. In
the wacitity, wastewater is collected in a channel and transmitted to
substances by applying various processes and finally it is
discharged.
-Renewable energy
BŞEÜ has 63 solar panels as renewable energy systems. 36 of these
panels are connected to the electricity grid of the university and
provide electricity. The remaining 27 are used for experimental
purposes.

\section{-Accessibility,}

Today, as important design criteria, supporting the quality of life; it is necessary to build egalitarian, safe, accessible and sustainable cities for people. In this sense, BŞÜ has carried out important studies on accessibility. BŞÜ T.C. It won the 3rd prize in the "Turkey Accessibility Awards Accessible Universities" category organized by the Ministry of Family, Labor and Social Services (URL 4, 2021).

Accessibility is provided by disabled ramps, floor differences, elevator transportation in building usage, and disabled parking lots at close distances at building entrances.

\section{-Clean transportation}

According to the American College and University President's climate commitment, some of main action options to reduce greenhouse gas (GHG) emissions are to adopt anenergy-efficient appliance and encourage the use of public transportation for all campus members (Vasquez et al. 2015). In order to reduce the use of motor vehicles in the university campus area, bicycles are available in front of the rectorate, available to all (Figure 4). In addition, since the units are located in the close distance in the campus area, it is not necessary to use a motor vehicle. Apart from this, academic and administrative staff, students and visitors are free to enter the campus area by vehicle. During periods of intense education, there is the use of vehicles and therefore harmful gases.

\section{-Use of recycled materials}

Use of natural stones provides advantages in terms of durability and recycling. Also wood, flexible and sustainable building material and are among the recyclable materials (Aydın and Alemdağ, 2014). So tThere are various pieces of furniture for the use of individuals in the campus area consisting of wood, stone and steel. This furniture can be recycled when they are damaged or removed from the area.

\section{- Sustainability of green areas:}

In recent years, it is noteworthy that plant material is used as a dominant element in environmental design projects made by both public and private institutions. University campuses, which are seen as an extension of urban habitats, are among the areas where intensive plant material is used for this purpose (Açıksöz et. al. 2014). The use of native plants (Peterson et. al. 2012) and plants with high water tolerance is very important in creating sustainable green spaces. Some of the plant inventory used in the open areas of BŞEÜ has been specified and it has been observed that content plants are used in terms of water demand. These plants 
are given in the table below (Table 3). There are ecologically, aesthetically and functionally interesting plant compositions in the campus area. Evergreen trees and shrubs, deciduous trees and shrubs, fruit trees, perennials and ground cover plants are the elements that form the green texture in the BŞEÜ campus. These plant species and their water requirements are given in Table 3.

-Creation of Alternative Green Areas

Although BŞEÜ seems to be sufficient in terms of green surfaces, there are concrete walls reaching 5 meters in some places. These walls can be considered as vertical walls to bring the campus in them aesthetically and ecologically.

Although there are green areas in the campus area, there are impermeable asphalt, concrete road, pavements, parking areas, hard floor activity areas. In these areas, buffer green surfaces and gravel surfaces can be preferred to separate pedestrian-vehicle traffic and increase permeable surfaces.

-Awareness in the field of education

Sustainability-related courses are included in the curricula of the departments of BŞEÜ. In this context, especially master's and doctoral students can be encouraged to the studies such as thesis and project in the fields of sustainability.

Table 3. Plant species on the BSEU campus

\begin{tabular}{ll}
\hline Plant Species & Water Request \\
Tilia tomentosa & Low \\
Aesculus hippocastanum & Medium \\
Pinus sylvestris & Low \\
Pinus brutia & Low \\
Platanus orientalis & Mediumü \\
Populus nigra & Low \\
Prunus avium & Medium \\
Punica granatum & Low \\
Prunus cerasifera & Medium \\
Malus domestica & Medium \\
Salix caprea & High/Medium \\
Fraxinus angustifolia & High \\
Cupressus macrocarpa' Goldcrest' & Low/ Medium \\
Cedrus libani (Orta) & Medium \\
Koelreuteria paniculata & Medium \\
Lagerstroemia indica & Low/ Medium \\
Cercis siliquastrum & Low/ Medium \\
Coteneaster franchetti & Low \\
Euonimus japonica 'Aurea' & Medium \\
Santolina chamaecyparissus & Low \\
Photinia fraserii & Medium \\
Lavandula angustifolia & Linus mugo \\
Hydrangea macrophylla & Medium \\
\hline
\end{tabular}




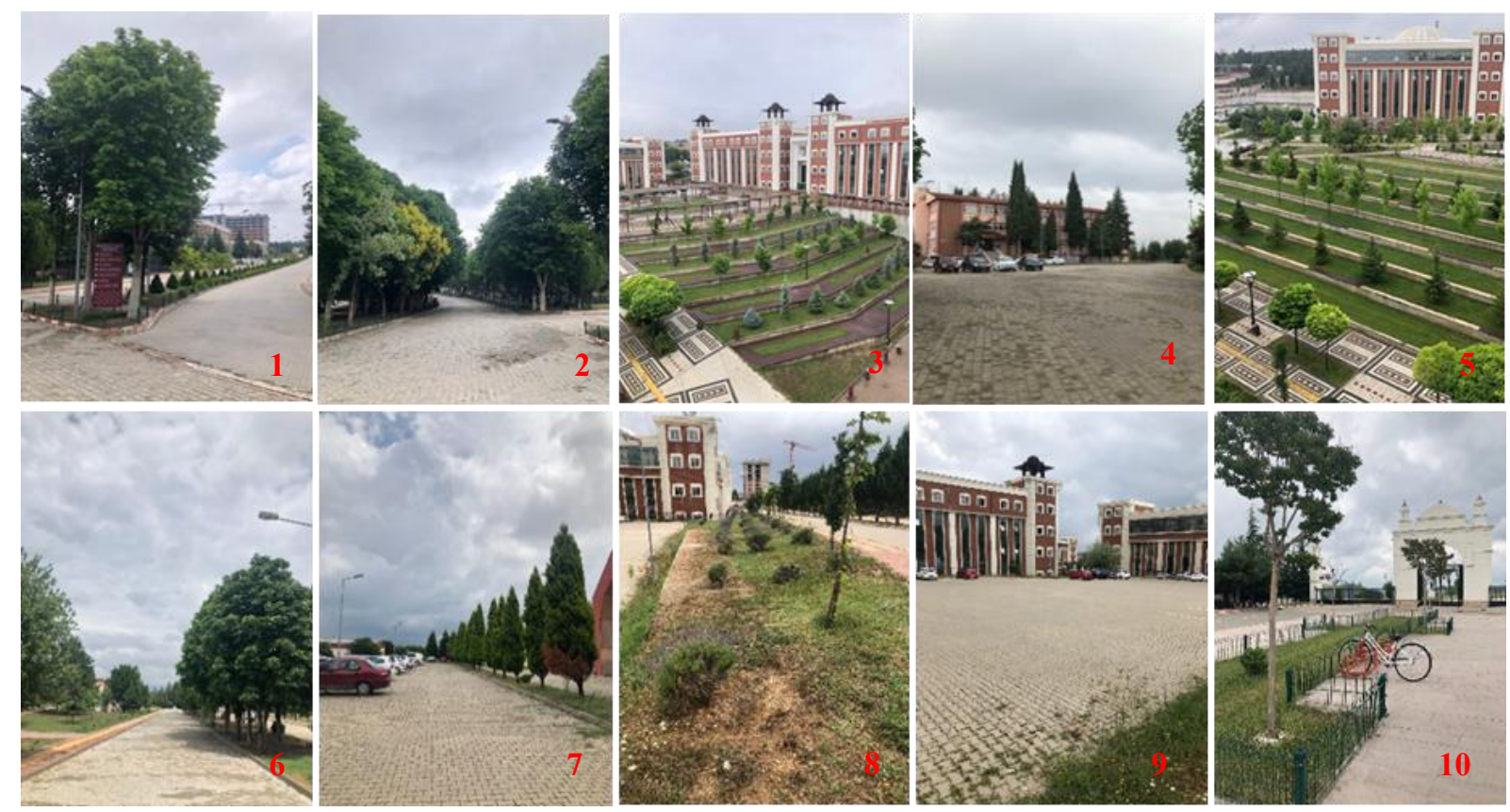

Figure 4. Images from the BSEU campus area (1-2-4-6: Main circulation, 3-5: Campus square (public areas; 7-9: Car park; 8: Green area separating car park and main road; 10; bike parking are)

\section{Conclusions and Recommendations}

Migration from villages to cities has increased with industrialization, and the increase in population in urban areas has caused many environmental problems. We started to encounter problems that are difficult to solve such as rapid consumption of natural resources in urban areas, solid waste problems, depletion of water resources with global warming, melting of glaciers. In order to solve or minimize these problems, it is necessary to start nature protection and improvement activities as soon as possible. Sustainable urbanization, conservation and improvement of natural resources integrates its purpose with the aim of social and economic development. In this sense, campus areas, which are the extensions of urban areas, can be selected as a small city model and sustainable approaches can be implemented. In this study, wastewater facility, solar panels, zero waste management, accessible transportation network, free use of bicycles, use of plants with medium/low water demand, and efficiently used green areas were specified in the BŞEÜ Gülümbe campus. Within the scope of sustainability, projects have been started in various units of the university for the reuse of wastewater and rainwater. The projects have been carried out on recycling and recycling of wastes as raw materials with the garbage bins placed in the units by the zero waste management unit. Bicycles in front of the Rectorate should also be placed at several different points of the university in order to reach more pedestrians. As a result, it has been seen that the sustainable solutions existing in the BŞEÜ campus should be emphasized and that there is a need for projects in wider application areas.

For a sustainable campus design, the following suggestions can be evaluated at the BŞEÜ campus;

- In the campus area with significant rainfall, rainwater should be stored by various methods and used for irrigation. Preventing the loss of water by surface flow by increasing rain ditches, rain gardens, and permeable surfaces, and directing the flow of water to storage units can be given as examples.
- In order to make green areas look rich and to save water, alternative ground cover plants can be used instead of grass surfaces with high water demand.

- In order to benefit from natural landscape elements, the use of indigenous plants can be increased, and the use of plants with high water tolerance from these plants can be encouraged. Also natural stones (marble, granite, basalt etc.) are recyclable and economical. Natural stone use leads to eco-friendly designs.

- The rock garden, which is the reflection of the natural landscape to the city, will also be efficient in water management on the BŞEÜ campus.

- Concept garden approaches can be included in the campus area for the landscape to be effective. For example, medicinal and aromatic herb gardens, hobby gardens are some of them.

- More energy can be obtained by increasing the number of solar energy systems used, and wind energy, which is another renewable energy, can also be taken into consideration.

- Ensuring ecologically sensitive and sustainable development of built environments in the campus area and city (LEED and ASLA certified)

- Landscape structures with unproductive soils or deteriorated by external factors should be improved and maintained.

- Sustainability-related courses can be increased in order to make students aware of the environment.

- Social events related to sustainability can be organized for both staff and students.

- Universities, which are a part of the city, should be a member of participants consisting of all relevant local groups in making decisions about the future of the city.

\section{Acknowledge}

Thanks to the units at Bilecik Seyh Edebali University that helped me to obtain data. 


\section{References}

Aydın, Ö. and Alemdağ, E. L. 2014. Karadeniz Geleneksel Mimarisinde Sürdürülebilir Malzemeler; Ahşap ve Taş, The Journal of International Social Research, Volume: 7 Issue: 35, Issn: 1307-9581.

Arıdağ, L. and Gürbüz, R., 2013. Sürdürülebilir Peyzaj Tasarimi İçin Asla Ve Leed Kriterlerinin Karşilaştirilmasi, Beykent Üniversitesi Fen Ve Mühendislik Bilimleri Dergisi, Cilt 6(2), $77-92$

Bayramoğlu E., Bekar, M., Kurdoğlu, B. Ç., 2020. Dikey bahçe tasarımın estetik ve işlevsel boyutu: KTÜ Kanuni Kampüs, Artvin Coruh University Journal of Forestry Faculty ISSN:2146-1880, e-ISSN: 2146-698X, Vol: 21, Issue:2, Pages: 223-230.

BEBKA (2018), T.C. Bursa Eskişehir Bilecik Kalkınma Ajansı, Doğa/Nature Bilecik, Seçil ofset.

Bilgili, M.Y. and Topal, A. 2021. Sürdürülebilir Yükseköğretim Kurumları Oluşturulmasında Talloires Deklarasyonunun Rolü ve Önemi, Journal of Higher Education and Science, 11(2), 417-424.

Cole L. 2003. Assessing Sustainability On Canadian University Campuses: Development Of A Campus Sustainability Assessment Framework, Assessing Sustainability of Canadian University Campuses.

Davis P.H., 1965. Flora of Turkey and the East Aegean Islands, Volume 1-9, Edinburgh University Press, Edinburgh, 19651985.

Dinçtürk C, Dal İ, Açıksöz S, 2020. Salgının Öğretileri ve Yeni Dış Mekân Kullanımları, Bartın Orman Fakultesi Dergisi, 22 (3): 791-801, DOI: 10.24011/barofd.773189.

EEA 1995, European Environment Agency annual report 1995, Erişim:

https://www.eea.europa.eu/publications/corporate_document _1995_1, 2021.

Erdoğan E. 2006. Çevre ve Kent Estetiği, ZKÜ Bartın Orman Fakültesi Dergisi, Cilt:8 Sayı:9

Erdem, C.B. 2018. Abbaslık Köyü (Bilecik) Florası Ve Etnobotanik Özellikleri, Hacettepe Üniversitesi Biyoloji Anabilimdalı, Y. Lisans Tezi, Ankara.

Emanuel, R. and Adams, J. N. (2010). College students' perceptions of campus sustainability, International Journal of Sustainability in Higher Education, Vol. 12 No. 1, pp. 79-92 Emerald Group Publishing Limited, 1467-6370, DOI 10.1108/14676371111098320.

Ertekin M and Çorbacı Ö L, 2010. Üniversite Kampüslerinde Peyzaj Tasarımı (Karabük Üniversitesi Peyzaj Projesi Örneği), Kastamonu Üni., Orman Fakültesi Dergisi, 10 (1): 55-67.

Günerhan, S., Günerhan, H. 2016. "Türkiye İçin Sürdürülebilir Üniversite Modeli," Mühendis ve Makina, cilt 57, say1 682, s. $54-62$.

Iş1ldar, G. Y., 2015. Sürdürülebilir Kentler İçin Üniversite Yerleşkelerinin Rolü, Yerel Politikalar, vol. 0, no. 1.

Kaplan, D.H. 2015. Transportation sustainability on a university campus, International Journal of Sustainability in Higher e-ISSN: 2148-2683
Education, Vol. 16 No. 2, 2015 pp. 173-186, Emerald Group Publishing Limited 1467-6370, DOI 10.1108/IJSHE-032013-0023

Karakurt Tosun, E. 2020. Sürdürülebilirlik Olgusu ve Kentsel Yapiya Etkileri, Ekonomi, Sosyoloji ve Politika Dergisi, (edergi), http://www.paradoks.org, ISSN 1305-7979, Y11:5 Say1:2.

Kop, A. 2011. Koruma Alanı Yakınındaki Hızlı Kentleşmenin Peyzaj Ekolojisi Yaklaşımı İle İrdelenmesi, İstanbul Teknik Üniversitesi Fen Bilimleri Enstitüsü, Y. Lisans Tezi, İstanbul.

Onur M. 2020. Covid-19 Salgın Döneminde Peyzaj ve İnsan İlişkisinin Mekânsal Tercihler Üzerinden İncelenmesi, Uluslararası Sosyal Araştırmalar Dergisi / The Journal of International Social Research, Cilt: 13 Sayı: 74.

Peterson, M. N., Thurmond, B., Mchale, M., Rodriquez, S., Bondell, H.D. and Cook, M., 2012. Predicting native plant landscaping preferences in urban areas, Sustainable Cities and Society, 5, 70-76.

Siu Yu Lau, S., Gou, Z. and Liu, Y. 2014. Healthy campus by open space design: Approaches and guidelines, Frontiers of Architectural Research 3, 452-467Open access under CC BY-NC-ND license.

Strokal, M., Bai, Z., Franssen, W., Hofstra, N., Koelmans, A.A., Ludwig, F., Ma, L., Puijenbroek, Spanier, J.E., Vermeulen, L.C., Vliet, M.T.H., Wijnen, J., Kroeze, J., 2021. Urbanization: an increasing source of multiple pollutants to rivers in the 21 st century. Urban Sustainability 1:24; https://doi.org/10.1038/s42949-021-00026-w.

Too, L. and Bajrachary, B. 2015. Sustainable campus: engaging the community in sustainability, International Journal of Sustainability in Higher Education, Vol. 16 No. 1,pp. 57-71.

Velazquez, L., Munguia, N., Platt, A. and Taddei, J. (2006), "Sustainable university: what can be the matter?", Journal of Cleaner Production, Vol. 14 Nos 9/10/11, pp. 810-819.

Vasquez, L., Iriarte, A., Almeida, M. and Villalobos, P. 2015. Evaluation of greenhouse gas emissions and proposals for theirreduction at a university campus in Chile, Journal of Cleaner Production, 108, 924-930.

Yıldız N E, 2020. Üniversite Yerleşkelerinde Ekolojik Peyzaj Tasarimi: Niğde Ömer Halisdemir Üniversitesi Örneği, Journal of Social and Humanities Sciences Research, 7(62), 3594-3604.

URL 1, (2021). http://www.bilecik.gov.tr/cografi-yapi.

URL 2,2021. http://greenmetric.ui.ac.id/

URL 3 , 2021 http://bildungskoalition.ch/media/medialibrary/2012/02/ISC N-GULF_Charter_Guidelines_20101027.pdf

URL 4, 2021. http://www.bilecik.edu.tr/Icerik/8409

URL 5, 2021. https://en.wikipedia.org/wiki/Sustainability_studies 